\title{
Improving the Quality of English Learning in Madrasah Tsanawiyah Muhammadiyah 10 Wukir at Wangen Using Lolly-Pop Card Media
}

\author{
Author \\ Riskha Aprilia Listianingrum, Dwi Yuliarti, Indah Yani, Andi Rahmad Rahim \\ Correspondence \\ Universitas Muhammadiyah Gresik \\ doi : 10.30587/kontribusia.v1i1.249 \\ URL:http://dx.doi.org/10.30587/kontribusia.v1i1.249

\begin{abstract}
The primary purpose of this article is to improve the quality of English learning process at MTs Muhammadiyah 10 Wukir by using Lolly-Pop Card media which is expected to make students more interested in learning English. In improving the quality of the learning process of English, the author also provides training in the making of learning media in the form of Lolly-pop Card. Participants who follow this English learning activity amounted to 6 people including formal educators. The results obtained after the training show that by using Lolly-pop Card media, the quality of English learning done by the teacher is better because it can improve the ability of learners in teaching activities and learners are more interested in learning English in the classroom. This is evidenced by the results of tests given after using Lolly-pop Card media. They are also more interested in learning to use Lollypop Card media so that the process of teaching and learning in the classroom is more active, fun, and not dull.
\end{abstract}

Keywords: Quality of English learning process, Lollypop Card.

\section{Introduction}

Teachers or educators are one of the essential elements of education. The quality standards of the teacher largely determine the excellent quality of education. Besides, a teacher must be competent, whether in the form of competencies of knowledge, understanding, abilities, values, attitudes, or interests. This is so that the teaching and learning process runs conducive and students will be more motivated in learning (E. Muljasa, 2003). From these aspects include several competencies including pedagogic competence, personality, professional, and social competence. In addition to competency, improving teaching and learning facilities is also an essential factor in improving competence. Not a strange sight if the teacher uses multimedia equipment or uses the media in the teaching and learning process. This will also improve teachers' professional competence which will have a positive impact on improving the quality of students.

The success of education can be measured by students' mastery of the material that has been conveyed by the teacher in the classroom. However, many of the operational successes are determined by education management in addition to being influenced by several institutional factors
Received: 10 April 2018. Accepted: 25 June 2018

that must exist and be related to it. These factors are (1) the teacher, (2) material, and (3) students.

The three main components of the teaching are interrelated. However, the teacher factor is the most dominant in teaching and learning activities. Teachers as planners as well as implementers of learning and feedback to motivate students in carrying out learning tasks. This shows that the position of teachers in the world of education is significant.

Based on that great function and role, ideally, a teacher must have professionalism in carrying out his duties. Being a professional teacher is not only a job demand but also an obligation of educators in the learning and teaching process. In addition to be a professional teacher, the ability or competence in providing positive feedback to students in the learning and teaching process is essential.

The ability or competence of teachers in providing the excellent education to students and in providing excellent quality teaching is the primary foundation in education. A teacher must be able to educate his students in a way that is good, to be able to shape the character of good students.

An educator or commonly known as a teacher must have creative ideas that can foster interest in 
and enthusiasm for students' learning. Especially in learning English. In English learning, for participants of MTs Muhammadiyah 10 Wukir is not easy learning. Therefore, the teacher's creative ideas for making new learning media are needed. Not only teachers but students also have a variety of creative ideas regarding learning English.

Students' creative ideas must be developed and must be honed, so they dare to express their opinions in public. Various fears of students can be minimized by the use of magnetic learning media, such as lollypop cards. English language learning media lollypop card is expected to minimize students' fear of communicating and interacting using English which is a foreign language in Indonesia, especially in Wangen Village, Glagah District, Lamongan Regency.

\section{Method}

\section{Activity Plan}

The activities carried out by this author aim to improve the quality of English learning more exciting and fun. With the training of making Lolly-pop Cards given by the author in Wangen village, precisely in MTs. Muhammadiyah 10 Wukir, many benefits are obtained. Besides being able to share knowledge, we can also establish a new brotherhood.

The target in making the Lolly-pop Card media is formal educators at MTs schools. Muhammadiyah 10 Wukir. This activity is also intended to add experience so that later it can be used as an expert in the teaching of students. Therefore, this design is made "interactive" with a system of "learning by doing" so that participants can interact directly with the teacher. This is very fun because the interactive teaching and learning process is indeed more fun than when you only hear and record the teacher's explanation. With an interactive learning process, students are stimulated to ask, answer, and express opinions. This learning system also does not emphasize the results but the process, so that students gain knowledge not by memorizing, but by experience.

\section{Materials and tools}

The material used in making Lolly-pop Card is the cardboard that we design to be like circular candy. Not only that, but we also need ice cream sticks and object images, as we also use double- sided adhesive tape and glue stick to make it look neat. The tools needed in making this media are only scissors as paper cutters. Also, in the manufacture of containers or media places for Lolly-pop Card media, we use used cardboard with the aim of utilizing the used goods around us, in addition to reducing waste, we can recycle unused goods and can be worth more and useful again.

\section{Problem Review}

MTs. Muhammadiyah 10 Wukir was chosen by the writer as a place of research because it was the place where the writer carried out the social program activities. Wangen Village is a village that has developed, where the residents of Wangen Village not only make a living as fishers but also have more varied livelihoods. The results of observations made by the authors regarding Wangen Village residents, it appears that their mindset has developed, and they are not fixated on conventional thinking. Besides, they also want the education in Wangen Village to be even better.

The results of the question and answer with the Wangen Village management stated that parents in Wangen Village had been very concerned about the quality of education for their children. This is evidenced by the thought of sending their children to school better even though they require the child to go far away or rent a boarding house and live separately with parents.

Before and during KKN activities take place, the author obtained the results of observations in the Wangen Village scope that the education in the village scope began to develop, where there were tutoring institutions established by the formal school educators. The level of education taught also varies starting from elementary school or junior high school. The material provided by the teacher also varies, some are under the curriculum in the school, and some are learning the material or other knowledge other than those found at the school.

Before and during the KKN process takes place, the results of observations in the Wangen Village are found that education within the village has also developed, where there are tutoring institutions established by the local school, formal educators. The level of education taught varies, starting from elementary and junior high schools. The material taught is more flexible, in addition to 
being adapted to the school curriculum, informal education like this can also provide material or other knowledge than those obtained at school. Both formal and informal education, at any level of education, media is needed in the teaching process. Starting from textbooks, student activity sheets, or examples of goods and other media that can help in the teaching and learning process. This includes teaching for English. The results of observation of the teaching and learning process of English language at MTs Muhammadiyah 10 Wukir showed that the teacher in this case taught with the help of the Student Activity Sheet (LKS), the teacher taught about the material in the LKS. The LKS media is colorless, only black and white on the pictures and less attractive to students. Then from these problems, it can be concluded that the needs of students (target need) in the process of learning English are learning media. After analyzing the problems of learning English and finding the target needs of students, the KKN team in group 3 of English Language Education Study Program then began designing and creating LollyPop Card media, because this media was considered as a solution to the problems that occurred to students and to meet the target needs.

The implementation of community service in the form of the application of English language learning media was carried out in one Madrasah Tsanawiyah, namely MTs Muhammadiyah 10 Wukir in Wangen Village, Glagah sub-district. The active role of students in implementing this media is very much needed so that the media can run effectively.

\section{Problem Settlement Framework}

Problem Identification

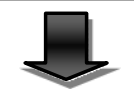

Target need analysis

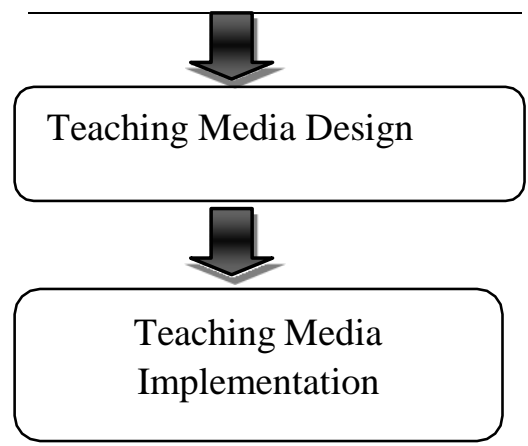

Figure 1. Problem Settlement Framework

\section{Data Retrieval}

The instructor has applied Lolly-pop Card media to several participants in the class after the training; we started taking samples to find out the results of the application of Lolly-pop Card media in teaching and learning activities. To collect data, we conducted observations and tests. The following are the results or data we obtained:
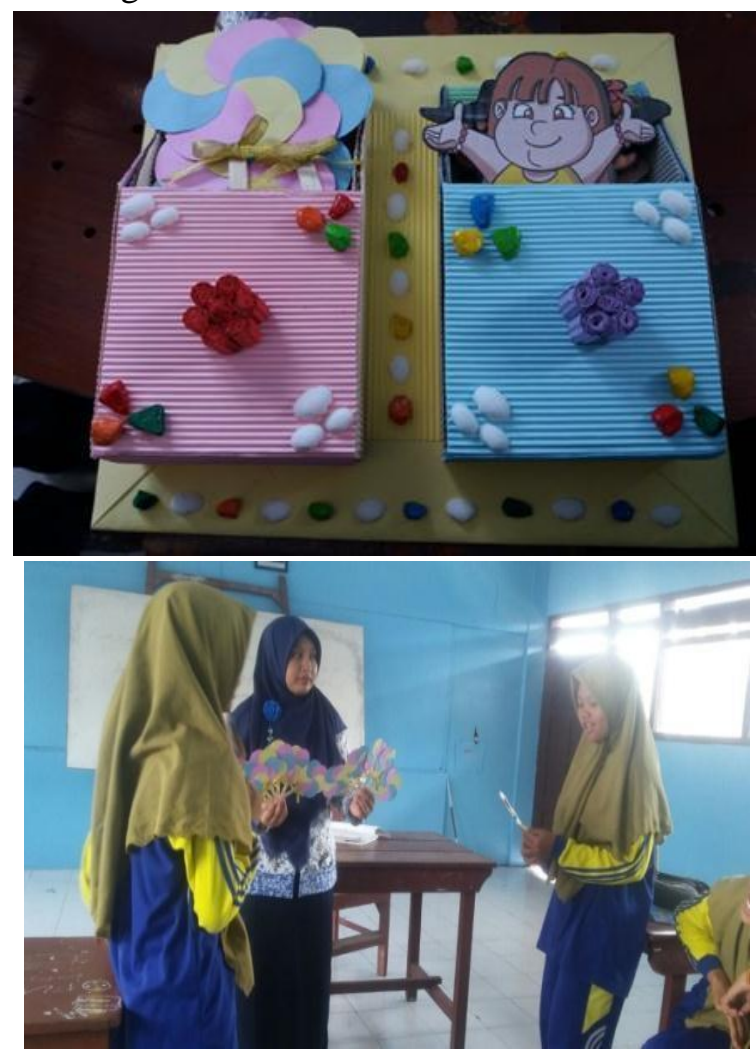


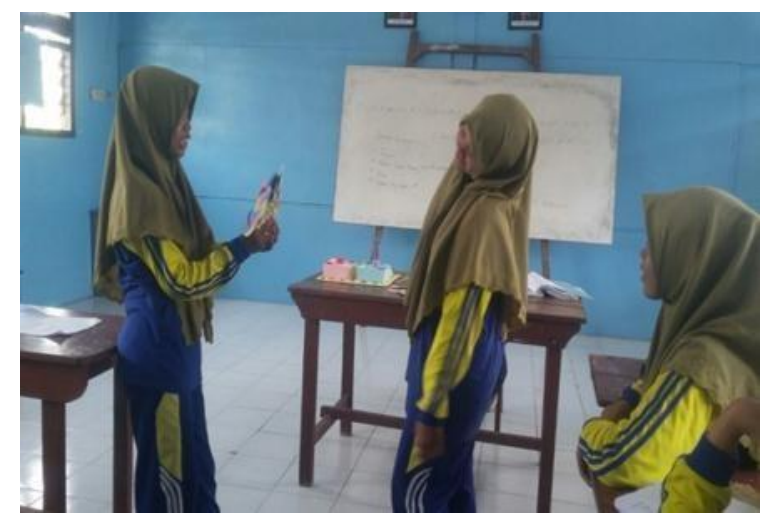

Figure 2. observations and tests

Below is the value of English for eighth-grade students of MTs. Muhammadiyah 10 Wukir about Expression of Like and Dislike with the topic of favorite foods and beverages, before using the Lolly-pop Card media:

\begin{tabular}{cll}
\hline No. & \multicolumn{1}{c}{ Student's name } & Value \\
\cline { 1 - 1 } 2. & Alfian Zulfanda Darajat & 73 \\
2. & Aisyah Azzaahidah & 70 \\
3. & Rosyidatul Jannah & 70 \\
4. & Zunita Mawar Fahrani & 72 \\
5. & Emy Lailatul Fajriyah & $\underline{74}$ \\
\hline
\end{tabular}

Below is the value of English for eighth-grade students of MTs. Muhammadiyah 10 Wukir about Expression of Like and Dislike with the topic of favorite foods and beverages, after using the Lollypop Card media:

\begin{tabular}{clll}
\hline No. & \multicolumn{1}{c}{ Student's name } & & Value \\
\cline { 1 - 1 } 1. & Alfian Zulfanda Darajat & Off \\
2. & Aisyah Azzaahidah & 93 \\
3. & Rosyidatul Jannah & 95 \\
4. & Zunita Mawar Fahrani & 86 \\
5. & Emy Lailatul Fajriyah & $\underline{80}$ \\
\hline
\end{tabular}

\section{TIME AND PLACE}

This activity took place followed by regular education personnel from MTs. Muhammadiyah 10 Wukir in Wangen village. The activity was carried out at $07.30 \mathrm{WIB}$ until finished at 11:30 WIB which coincided at MTs school. Muhammadiyah 10 Wukir.

\section{Solution}

According to Thornbury (2007), visualizing is the best way to teach new words to all subjects. Furthermore, Thornbury said that using images is ideal for teaching students. In this case, teaching about language will be significantly helped by the visualization and images that can attract students. Moreover, one way that can be done is by using the learning media.
Learning media is material used for educational purposes. One example that fits the above principles is Lolly-pop Card. Lolly-pop Card is an innovation of flash cards where flash cards are visual learning media that contain words, pictures, or a combination of them (Basuki Wibawa \& Farida Mukti, 1991: 30). This is following the understanding of flash cards according to Dina Indiana (2011: 68-69) flash cards are learning media in the form of a picture card measuring 25 $\mathrm{cm} \times 30 \mathrm{~cm}$. The displayed image can be in the form of hand drawings or existing photos and then pasted on the card sheets.

Meanwhile, according to Azhar Arsyad (2011: 120-121), flash cards are cards that contain pictures (objects, animals, etc.) that can be used to train children to spell and enrich vocabulary. Basically, the use of the Lolly-Pop Card media is the same as a flash card, but the difference is in the shape, the shape is like lolly-pop candy, Lolly-pop Card is made of colorful cardboard and sticks as a support and there is a ribbon as a decoration to make it look like lolly- real pop. The back contains images. The images used are suitable for the material to be taught and colored, which attracts students' attention and increases their motivation. The use of Lolly-pop Card media like this is expected to help educators to explain the English language material taught. This media is also expected to increase students' interest in learning English.

\section{Results and Discussion}

From the teaching media doing training in the form of Lolly-pop Cards that we conducted on February 3, 2018, to February 17, 2018, every Saturday and Sunday to formal educators or lecturers at MTs Muhammadiyah 10 Wukir, we received responses, criticisms and suggestions from participants. Participants who took part in this media creation training were very enthusiastic and happily exchanged ideas or knowledge because the initial purpose of this training was to share experiences in becoming an educator. Next, we attach the results of the questionnaire from the participants: 


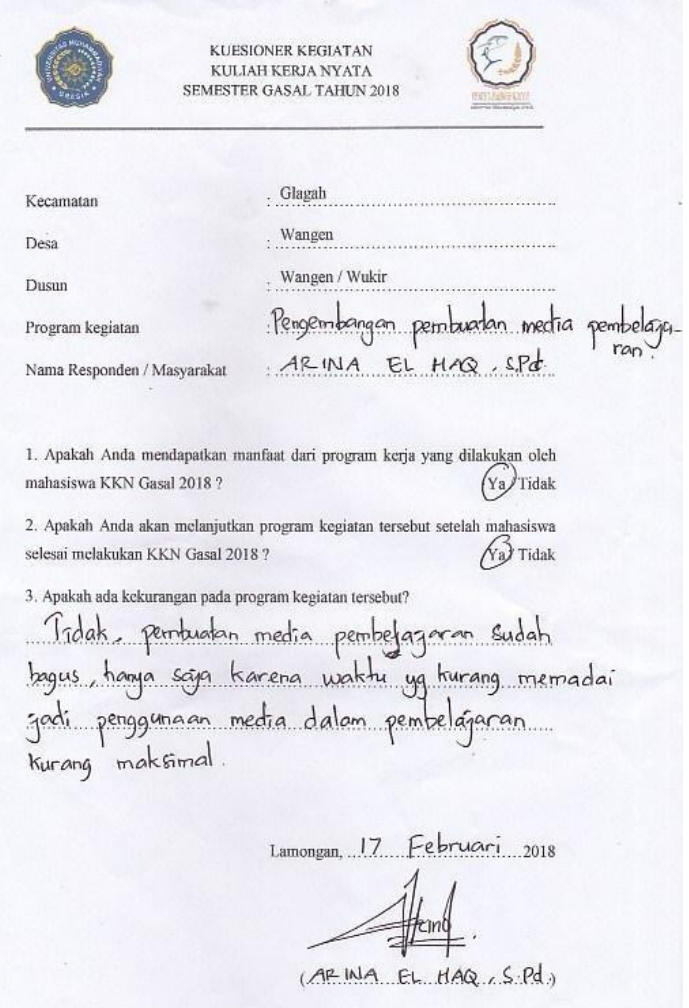

Figure 3. questionnaire from the participants

From the questionnaire we received, it seems that participants benefited from the training we provided, gained new knowledge, new material, new media, and new inspiration in teaching. In this training, the participants planned to implement Lolly-pop Cards as a media in teaching them. For the whole training and response from the participants that is good and strongly agree if the Lolly-pop Card media is applied in the teaching and learning process.

\section{Conclusion}

The primary purpose of this article is to improve the quality of English teaching using the Lolly-pop Card media. In its improvement, the author provided training in making Lolly-pop Card media. MTs English teachers attended this training. Muhammadiyah 10 Wukir, Wangen village. The results of the training provided by the author stated that using Lolly-Pop Card media in the teaching and learning process can improve the ability of students in English, this is evidenced by the learning outcomes of students after learning to use the Lolly-pop Card media, not only that The author also made observations, the results of the observations also showed that students were more interested in learning English by using the media and they felt happy when they used the media. So that the learning process in the classroom becomes active, fun, exciting, and not dull.

\section{References}

Arsyad, A. (2011). Media Pembelajaran. Jakarta:

Raja Grafindo Persada.

E., Muljasa. (2003). Kurikulum Berbasis K

ompetensi. Bandung: PT. Remaja Rosda Karya.

Indriana, D. (2011). Ragam Alat Bantu Media

Pengajaran. Yogyakarta: Diva Press.

Thornburry, S. (2007). How to Teach Vocabulary.

Oxford: Longman Group.

Wibawa, B., \& Mukti, F. (1991). Media

Pengajaran. Jakarta: Departemen Pendidikan

dan Kebudayaan, Direktorat Jenderal

Pendidikan Tinggi, Proyek Tenaga

Kependidikan 